口腔領域に発生した軟部肉腫の臨床病理学的検討

\author{
新谷＼cjkstart悟・浜川裕之・住田知樹 \\ 中原裕二·李 春男・鎌田道子
}

\title{
A clinicopathological study of oral soft tissue sarcomas
}

\author{
Satoru Shintani $\cdot$ Hiroyuki Hamakawa $\cdot$ Tomoki Sumida \\ Yuji NaKahara $\cdot$ Shunnan Li $\cdot$ Michiko Kamata
}

\begin{abstract}
Because soft tissue sarcoma rarely arises in the oral cavity, there are few reports on this lesion in the head and neck region. Eight cases of soft tissue sarcoma treated at our department during the past two decades were studied clinicopathologically. Some small lesions were clinically given a diagnosis of benign tumor at presentation, followed by excisional biopsy. It was difficult to achieve an exact pathologic diagnosis from the biopsy specimens. The definitive diagnosis based on the resected material differed from the original diagnosis in some cases. Six of the eight cases were subjected to immunostaining to analyze their cytologic characteristics. Alteration of the p53 tumor suppressor gene was detected in 4 cases, and loss of p16 was noted in 5 cases. The average proliferation cell nuclear antigen labeling index of the soft tissue sarcomas was $31.3 \%$, higher than the value for oral squamous cell carcinoma. All soft tissue sarcomas expressed metalloprotease (MMP) - 2 and MMP- 9 and showed low intratumoral microvessel density. These results suggest that soft tissue sarcomas have high proliferation potential and aggressive growth without angiogenesis.
\end{abstract}

Key words: oral (口腔), soft tissue sarcoma (軟部肉腫), cell proliferation (細胞増殖), angiogenesis (血管新 生)

緒言

軟部肉腫は, 線維性組織, 脂肪組織, 筋肉, 滑膜, 血管, 神 経などの種々の非上皮性組織を発生母地とする悪性腫瘍で あり，きわめて多彩な臨床像ならびに組織学的所見を呈す ることから,診断は必ずしも容易ではない.頭頸部悪性腫 瘍における軟部肉腫の割合は約 $1 \%$ 以下であり, 口腔内の 発生頻度はさらに少ない1，2，本腫場は急速に発育増殖 し，扮もに血行性に肺，肝，骨髄などに，またりンパ行性に 頸部リンパ節に早期に転移を示し, 予後は悪い1，2）。

今回，われわれは過去 20 年間に当科で加療した軟部肉腫 8 例に対し, 臨床診断, 病理組織学診断, 腫瘍の細胞増殖能 と細胞増殖に関連する癌抑制遺伝子の異常，そして浸潤， 転移に関連する因子としてマトリックスメタロプロテアー

愛媛大学医学部歯科口腔外科学講座

(主任：浜川裕之教授)

Department of Oral and Maxillofacial Surgery, Ehime

University School of Medicine (Chief: Prof. Hiroyuki

Hamakawa)

受付日：平成13年 7 月 4 日
ゼ (MMP) の MMP-2, MMP-9 と腫瘍内血管について 検討した。

\section{対象ならびに方法}

\section{対象}

対象は1980年から1999年の過去20年間に愛媛大学医学部 歯科口腔外科にて加療した軟部肉腫 8 例である.

\section{臨床病理学的検討}

対象症例の, 性別, 年齢, 発生部位, 臨床経過などの臨床 的因子と生検時および最終組織診断について検討した。

\section{免疫組織化学的検討}

病理組織学的検索のために, 10\%中性緩衝ホルマリン溶 液にて固定後, パラフィン包埋された生検材料ならびに切 除腫瘍組織を検討に用いた。通法に従い $4 \mu \mathrm{m}$ のパラフィ ン薄切切片を作製し， ENVISION システム（Dako 社製） により免疫組織化学染色を行った. すなわち, 通常通り脱 パラフィン後, 内因性ペルオキシダーゼ阻止を行い, 一次 抗体をおの扔のの希釈倍率にて, $4{ }^{\circ} \mathrm{C} て ゙ 16$ 時間反応させた 
表 1 一次抗体と前処理

\begin{tabular}{lccl}
\hline \multicolumn{1}{c}{ 抗 体 } & 希釈倍率 & 前処理 & \multicolumn{1}{c}{ 入 } \\
\hline PCNA (PC-10, IgG 2a) & $1: 300$ & & 先 \\
p53 (DO- 7) & $1: 50$ & MW & Dako patts (Denmark) \\
pRb (Ab-5) & $1: 300$ & MW & Oncogene Research (MA, USA) \\
p16 (F-12) & $1: 50$ & MW & Santa Cruz Biotechnology (CA, USA) \\
MMP-2 & $1: 50$ & MW & Sigma (MO, USA) \\
MMP-9 & $1: 50$ & MW & Sigma (MO, USA) \\
CD31 (JC $/ 70 A)$ & $1: 50$ & Trypsin & Dako patts (Denmark) \\
\hline
\end{tabular}

MW; Microwave $20 \mathrm{~min}$.

Trypsin: $0.1 \%$ trypsin treatment $37^{\circ} \mathrm{C}, 1 \mathrm{hr}$.

表 2 臨床所見と臨床診断

\begin{tabular}{|c|c|c|c|c|c|c|c|c|c|}
\hline & 性別 & 年齢 & 発生部位 & 大きさ & 硬さ & 境界 & 視診型 & 疼痛 & 臨床診断 \\
\hline 1 & 女 & 21 & 左側上顎歯肉 & $10 \times 25 \mathrm{~mm}$ & 弾性硬 & 明 瞭 & 膨隆型 & な & 上 顎 腫 瘍 \\
\hline 2 & 男 & 55 & 左 側 上顎 洞 & $40 \times 55 \mathrm{~mm}$ & - & - & - & 自発痛 & 上 顎 腫 瘍 \\
\hline 3 & 男 & 40 & 左側下顎歯肉 & $42 \times 55 \mathrm{~mm}$ & 弾性硬 & 不明瞭 & 膨隆型 & 圧 痛 & 非上皮性腫瘍 \\
\hline 4 & 女 & 64 & 右 側顎 下 部 & $50 \times 70 \mathrm{~mm}$ & 弾性硬 & 不明瞭 & 膨隆型 & 自発痛 & 甲状腺癌再発 \\
\hline 5 & 男 & 45 & 右側下顎歯肉 & $16 \times 25 \mathrm{~mm}$ & 弾性軟 & 不明瞭 & 腫瘤型 & 自発痛 & 下顎歯肉腫瘍 \\
\hline 6 & 男 & 76 & 左側下顎歯肉 & $40 \times 57 \mathrm{~mm}$ & 弾性硬 & 明 瞭 & 腫瘤型 & な & 左 側下顎 癌 \\
\hline 7 & 女 & 31 & 右 側 煩 部 & $24 \times 24 \mathrm{~mm}$ & 弾性硬 & 明 瞭 & 膨隆型 & な & 煩 部 腫 瘍 \\
\hline 8 & 男 & 68 & 右側上顎歯肉 & $25 \times 35 \mathrm{~mm}$ & 弾性硬 & 明 瞭 & 腫瘤型 & 圧 痛 & 右側上顎 癌 \\
\hline
\end{tabular}

（表1). 次にEnvision ポリマー試薬を室温で30分間反応 後, DAB ( $3-3^{\prime}$-diaminobenzadine - $\left.4 \mathrm{HCl}\right)$ にて発色さ せ, メチルグリーンにて対比染色後, 脱水, 透徹, 封入し検 鏡した. 前処理として Target Retrieval Solution（Dako 社) 中でマイクロウエーブ処理 (マイクロウエーブオーブ ン：シャープ社製出力 $500 \mathrm{~W}) 20$ 分間ならびに0.1\%トリプ シン溶液中で $37^{\circ} \mathrm{C}, 1$ 時間処理した.

陽性細胞率は, 以前の報告と同様に, 強拡大顕微鏡写真 下で無作為に少なくとも 3 か所, 1000個以上の腫瘍細胞を 抽出し, 陽性細胞数の割合として算定した ${ }^{3,4)}$. p $53, \mathrm{pRb,}$ p16の評価についても，以前の報告に準じ，陽性細胞率 $5 \%$ 以上のものを陽性とした ${ }^{5,6)}$. MMP-2, MMP- 9 に関し ては, Banassi らの方法に準じて健常組織との比較により 行い, 腫瘍内血管密度 intratumor microvessel density (ITMVD) は, 200倍検鏡下，一視野内での CD31陽性血管 数を算定した ${ }^{3,4)}$.

$$
\text { 結果 }
$$

\section{臨床所見ならびに臨床経過}

1980年から1999年の過去20年間に愛媛大学医学部歯科口 腔外科にて加療した顎口腔領域悪性腫瘍は258例であり, 軟部肉腫 8 例はその $3.1 \%$ であた. 症例の性別は男性 5
例, 女性 3 例, 年齢は21歳から 68 歳で平均 50.0 歳であった。 発生部位では下顎歯肉 3 例, 上顎歯肉 2 例, 上顎洞, 煩部, 顎下部が 1 例であった. 最終組織学的診断としては, 覀性 線維性組織球腫 2 例, 横紋筋肉腫 2 例, 平滑筋肉腫, 悪性神 経鞘腫, 未分化肉腫, 腎外性悪性 Rhabdoid 腫瘍が, おのお の 1 例であった. 各症例の臨床所見では, 大きさは $10 \times 25$ $\mathrm{mm}$ 程度のものから $50 \times 70 \mathrm{~mm}$ のものまでみられ，ほとん どの症例で弾性硬の腫瘤として認められた. 境界は明瞭が 4 例, 不明瞭が 3 例であり, 肉眼的視診型でも膨隆型 4 例, 腫瘤型 3 例であった。

初診時の臨床診断はおおむね悪性腫瘍であったが, 腫瘍 径の小さい症例（症例 1 ならびに 7 ）では, 良性腫瘍と考 え, 切除生検を試みていた. 症例 5 も $16 \times 25 \mathrm{~mm}$ と腫瘍径 は大きくなかったが, オトガイ孔部に激痛を訴え同部の骨 破壊像を認めたことから，臨床的に悪性を疑った（表 2 ).

臨床経過ならびに予後では, 手術を行った 6 例中 3 例に 局所再発を認め, 8 例中 6 例で遠隔転移を認めた. また, 予 後も 2 例を除き不良であった（表 3 ).

\section{生検時と最終病理組織学的診断}

生検時と最終病理組織学的診断では, 生検時におおむね 非上皮性悪性腫瘍の診断が得られていた. 近年では, 免疫 組織染色の日常化によって生検時の組織標本でケラチン, 
表 3 軟部肉腫の臨床経過ならびに予後

\begin{tabular}{|c|c|c|c|c|c|}
\hline & \multirow{2}{*}{ 組 織学 的診断 } & \multirow{2}{*}{ 治 療 } & 臨 & 床 経 過 & \multirow{2}{*}{ 予 } \\
\hline & & & 局所再発 & 転 & \\
\hline 1 & 横紋筋肉腫 & $\mathrm{S}+\mathrm{R}+\mathrm{C}$ & $3 \mathrm{M}$ & 骨盤内 ( 6 Y 10M) & 死 ( $7 Y)$ \\
\hline 2 & 悪性線維性組織球腫 & $\mathrm{S}+\mathrm{R}+\mathrm{C}$ & $10 \mathrm{M}$ & 肩甲骨（１Ｙ２Ｍ） & 死 ( 2 Y $7 \mathrm{M})$ \\
\hline 3 & 横紋筋肉腫 & $\mathrm{S}+\mathrm{R}+\mathrm{C}$ & なし & 多発性骨 (10M) & 死 (1 Y $3 \mathrm{M})$ \\
\hline 4 & 腎外性悪性 Rhabdoid 腫瘍 & $\mathrm{R}+\mathrm{C}$ & $\mathrm{NE}$ & 肺 & 死 ( $5 \mathrm{M})$ \\
\hline 5 & 悪性神経鞘腫 & $\mathrm{S}+\mathrm{R}+\mathrm{C}$ & $5 \mathrm{M}$ & 多発骨 ( $6 \mathrm{M})$ & 死 (10M) \\
\hline 6 & 平滑筋肉腫 & $\mathrm{R}+\mathrm{C}$ & $\mathrm{NE}$ & 肺 & 死 ( $3 \mathrm{M})$ \\
\hline 7 & 悪性線維性組織球腫 & $\mathrm{S}+\mathrm{C}$ & なし & なし & 生 ( 3 Y $2 \mathrm{M})$ \\
\hline 8 & 未分化肉腫 & $\mathrm{S}$ & なし & なし & 生 ( $2 \mathrm{Y})$ \\
\hline
\end{tabular}

$\mathrm{S}$; 手術, $\mathrm{R}$; 放射線治療, $\mathrm{C}$; 化学療法

$\mathrm{NE}$; 評価不能

表 4 生検時の診断と最終診断

\begin{tabular}{|c|c|c|c|}
\hline & 初診時臨床診断 & 生検時病理診断 & 最 終 診 \\
\hline 1 & 上顎 腫 瘍 & 悪性非上皮性腫瘍 & 横紋筋肉腫 \\
\hline 2 & 上顎 腫 瘍 & 線維性組織球腫 & 悪性線維性組織球腫 \\
\hline 3 & 非上皮性腫 瘍 & 平滑筋肉腫 - 線維肉腫 & 横紋筋肉腫 \\
\hline 4 & 転移性甲状腺癌 & 腎外性悪性 Rhabdoid 腫瘍 & 腎外性悪性 Rhabdoid 腫瘍 \\
\hline 5 & 非上皮性腫 瘍 & 悪性神経鞘腫 & 悪性神経鞘腫 \\
\hline 6 & 上顎癌 & 平滑筋腫 - 紡錘細胞癌 & 平滑筋肉腫 \\
\hline 7 & 煩 部 腫 瘍 & 類上皮系肉腫 & 悪性線維性組織球腫 \\
\hline 8 & 上顎癌 & 横紋筋肉腫 & 未分化肉腫 \\
\hline
\end{tabular}

表 5 腫瘍増殖能と癌抑制遺伝子産物の発現

\begin{tabular}{llcccc}
\hline \multicolumn{1}{c}{ 組織学的診断 } & $\mathrm{p} 53$ & $\mathrm{pRb}$ & $\mathrm{p} 16$ & PCNA L.I. $^{*}$ \\
\hline 1 & 横紋筋肉腫 & $\mathrm{NE}$ & $\mathrm{NE}$ & $\mathrm{NE}$ & $\mathrm{NE}$ \\
2 & 悪性線維性組織球腫 & - & + & - & $32.0 \%$ \\
3 & 横紋筋肉腫 & + & + & - & $25.3 \%$ \\
4 & 腎外性悪性 Rhabdoid 腫瘍 & $\mathrm{NE}$ & $\mathrm{NE}$ & $\mathrm{NE}$ & $\mathrm{NE}$ \\
5 & 悪性シュワン鞘腫 & + & + & - & $38.8 \%$ \\
6 & 平滑筋肉腫 & + & + & + & $34.1 \%$ \\
7 & 悪性線維性組織球腫 & - & + & - & $25.5 \%$ \\
8 & 未分化肉腫 & + & + & - & $32.2 \%$ \\
\hline
\end{tabular}

$\mathrm{NE}$; 評価不能

ビメンチン, アクチン，ミオグロブリン, EMA, S-100など を検索しているが, 各組織型の診断までは確定し得ていな い症例が多かった（表 4 ）。

\section{細胞増殖能ならびに癌抑制遺伝子産物}

対象症例の 8 例中 6 例で十分な免疫組織化学的検索が可 能であった. Proliferating cell nuclear antigen (PCNA) ならびに癌抑制遺伝子産物の $\mathrm{p} 53, \mathrm{pRb}, \mathrm{p} 16$ の免疫染色で は, いずれも核に陽性所見を認めた（写真 1 ).
PCNA L.I.は25.3\%から $38.8 \%$ ，平均 $31.3 \%$ であった。 $\mathrm{p} 53$ の異常は6 例中 4 例 $(66.7 \%)$ に, pRbは全例に陽性を 示し, p16蛋白の欠失は 6 例中 5 例 $(83.3 \%)$ に認められた (表 5 ).

\section{MMP の発現と腫瘍内血管}

MMP- 2 およびMMP- 9 の免疫染色では, 腫瘍の細胞質 にびまん性にその発現を認め, すべての検索症例で陽性所 見を示した. 腫瘍内血管については CD31により免疫染色 


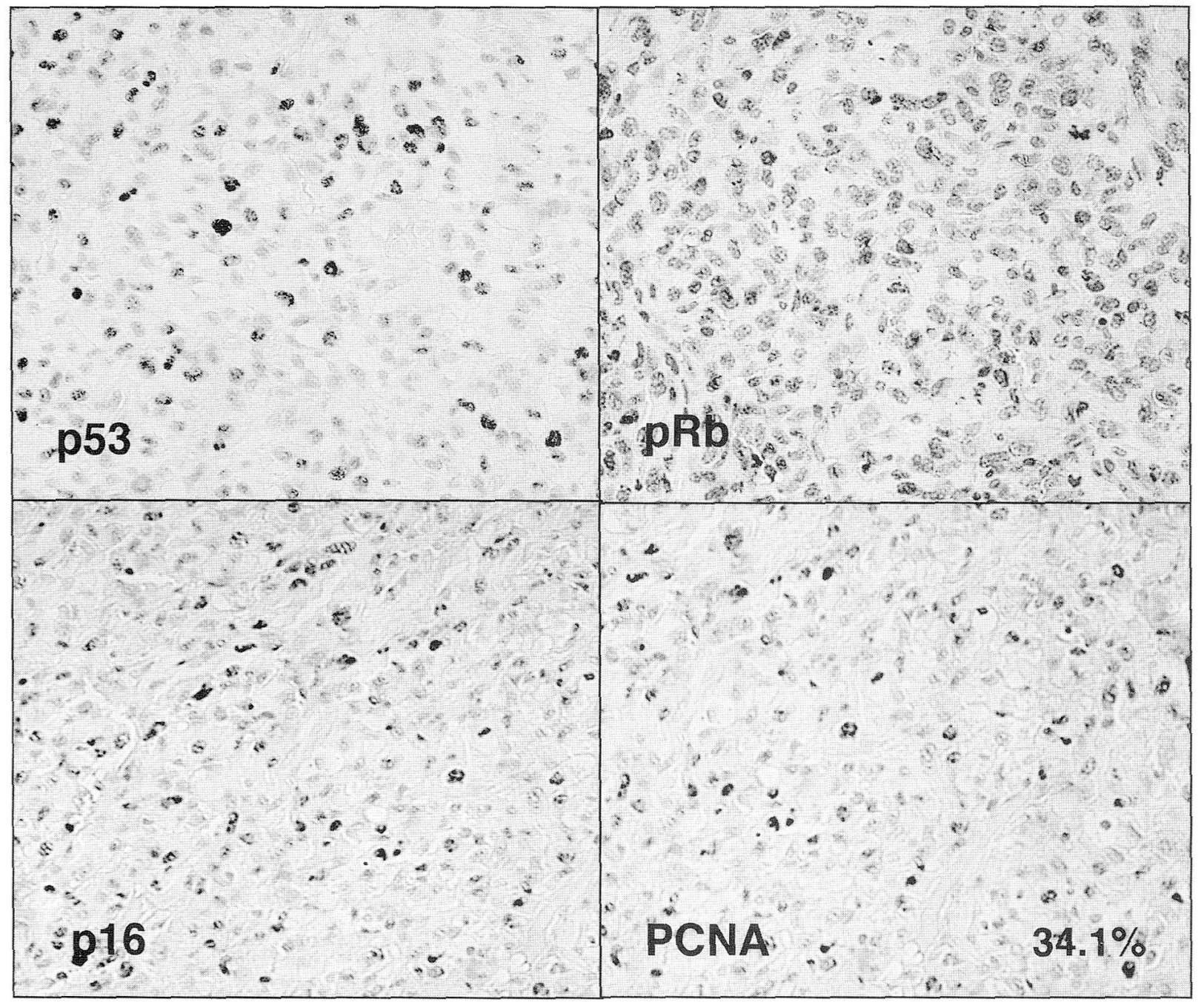

写真 1 病理組織像（抗 553 , 抗 $\mathrm{pRb}$, 抗 $\mathrm{p} 16$ ならびに抗 PCNA 抗体による免疫染色 $\times 200$ ) 症例 6 における癌抑制遺伝子産物の p 53, pRb, p16ならびに proliferating cell nuclear antigen (PCNA)の染色 $(\times 200)$.いずれも核に陽性所見を示す。

したが, 扁平上皮癌とは異なり，腫瘍間質がほとんどなく， 血管も腫瘍周囲に扔いて健常組織部分にすでに存在してい たであろう比較的太い毛細血管を腫瘍が囲㤩という形でし か観察されなかった。また，腫瘍が血管を破壊するような 像も認められた。腫澔内血管密度に関しては, 2.3 から 11.6 ／area と非常に低値であった (写真 2, 表 6 ).

\section{考察}

\section{臨床所見ならびに臨床経過}

頭頸部に発生する軟部肉腫は全体の $20 \%$ 以下といわれて いる1). 頭頸部悪性腫瘍のなかでの軟部肉腫の占める割合 は $1 \%$ \%下であるとされ ${ }^{1}$ ), Gorsky ら ${ }^{2)}$ も, 頭頸部腫瘍 の $1.4 \%$, 口腔領域では $0.14 \%$ の発生頻度であったと報告し ている.われわれの施設の発生頻度は3.1\%と，過去の報告
に比して高かった。本腫瘍はその発生母地が非上皮性であ ることから, 多様な部位に多様な病態を呈する。一般的に 肉腫の初発症状としては無痛性の腫脹として現れることが 多いとされている1).今回の検討に扮いても，8例中 5 例 は無痛性で弾性硬の腫瘤として認められた。自発痛を認め た 3 例では, オ卜ガイ神経に発生した神経鞘腫の 1 例以外 の2例でいずれも腫瘍径が大きかったことから，腫瘍の大 きさと自発痛との関連が示唆された. 腫瘍径の大きいもの や, 骨破壊像などの周囲組織への浸潤が明らかなものでは, 臨床的にも悪性腫瘍を疑っていたが, 腫瘍径の小さく境界 の明瞭な症例（症例 1 ならびに 7 ）では，臨床的に良性腫 瘍と考光，切除生検を試みていた。これらの症例では，臨床 所見から悪性と診断することは困難であると考えられた。 症例 5 は $16 \times 25 \mathrm{~mm}$ と腫瘍徍は大きくなかったが，オトガ イ孔部に激痛を訴え同部の骨破壊像を認めたことから，臨 


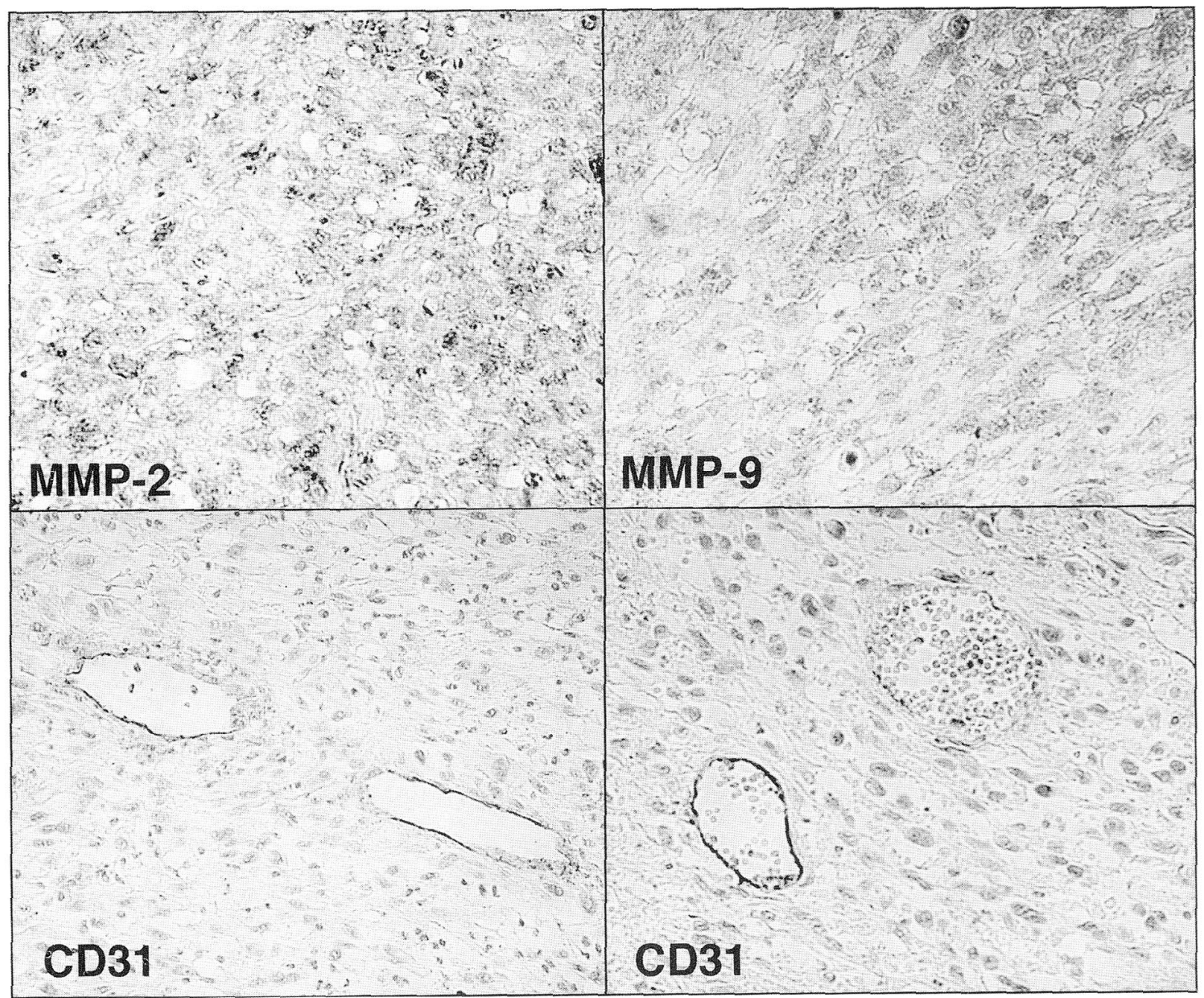

写真 2 病理組織像（抗 MMP-2, 抗 MMP-9ならびに抗 CD31抗体による免疫染色 ×200）

症例 6 における MMP-2，MMP-9ならびにCD31による腫瘍血管の評価. MMP-2，MMP-9 は発現を認めたが， 腫瘍内に血管はほとんど認められなかった。

表 6 マトリックスメタロプロテアーゼー2, - 9の発現と腫演内血管密度

\begin{tabular}{|c|c|c|c|c|}
\hline & 組織学的診断 & MMP - 2 & MMP- 9 & ITMVD $^{*}$ \\
\hline 1 & 横紋筋肉腫 & $\mathrm{NE}$ & $\mathrm{NE}$ & $\mathrm{NE}$ \\
\hline 2 & 覀性線維性組織球腫 & + & + & 7.3 \\
\hline 3 & 横紋筋肉腫 & + & + & 11.6 \\
\hline 4 & 腎外性悪性 Rhabdoid 腫瘍 & $\mathrm{NE}$ & $\mathrm{NE}$ & $\mathrm{NE}$ \\
\hline 5 & 悪性神経鞘腫 & + & + & 4.3 \\
\hline 6 & 平滑筋肉腫 & + & + & 2.3 \\
\hline 7 & 悪性線維性組織球腫 & + & + & 2.3 \\
\hline 8 & 未分化肉腫 & + & + & 5.6 \\
\hline
\end{tabular}

$\mathrm{NE}$; 評価不能

ITMVD; Intratumorl microvessel density 
床的に悪性を疑った。このような慎重な診断が大切である ことを改めて認識した. 臨床経過では, 局所再発, 遠隔転移 が認められ, 予後は悪かった。

\section{生検時と最終病理組織学的診断}

軟部肉腫は, 組織形態的な特徵すなわち分化傾向で分類 される. 本腫瘍は, 非上皮性組織を母地として発生し, 多様 な組織像を示す.おのおのの軟部肉腫がどの分化傾向をも つかは腫瘍全体をみて判断されるため生検材料で確定診断 を与えることは非常に困難である.今回の検索でも，生検 時に非上皮性悪性腫瘍の診断はされていたが, 組織型では, 多くの症例で最終診断と異なっていた。症例 2 は, 生検時 線維性組織球腫と診断され，姑息的に腫場摘出術を施行後， 肩甲骨に転移を認めた症例であるが, 病理組織学的には最 後までWeissの診断基準 7) には合致しなかった。この症例 の詳細はすでに報告しているが8), 線維性組織球腫に関し ては1994年改訂されたWHO 分類 ${ }^{9}$ )でも良性, 悪性に加え 中間の Intermediateを分類するなど議論の多いところで あり，それを生検材料などの限られた材料で診断すること は困難であると思われた。

\section{細胞増殖能ならびに癌抑制遺伝子産物}

PCNA L.I.は25.3\%から $38.8 \%$ であり平均 $31.3 \%$ であっ た. 口腔扁平上皮癌におけるPCNA L.I.は16\%ないしは約 $20 \%$ であり 3,5 ，軟部肉腫の高い増殖活性が示唆された。

p53遺伝子は染色体 $17 \mathrm{p}$ に存在し, 野生型 p53遺伝子産物 は53kDa の核リン酸化蛋白である ${ }^{10)}$. 野生型 $\mathrm{p} 53$ 遺伝子産 物は, 腫瘍の細胞増殖やアポトーシスを制御している11). p53の異常は, 口腔癌を含む種々の癌の約 $50 \%$ に生じてい るが12,13), 検索において, 軟部肉腫での異常は $66.7 \%$ に認 められ，ほほ同様かやや高い頻度で異常が生じていること が示された. Ayan らは, 横紋筋肉腫の症例において p53の 異常が臨床病理学的所見や遠隔転移, 予後不良と関連する ことを報告しており興味深い14).

$\mathrm{Rb}$ 蛋白は転写因子 $\mathrm{E} 2 \mathrm{~F}$ などと結合し, 活性型の $\mathrm{Rb}$ 蛋 白として機能し, 細胞周期を G 1 期に停止させるように働 く. Rb 蛋白が cyclin D / CDK 4（6）によりリン酸化され 過リン酸型 $\mathrm{Rb}$ 蛋白に変換されると, 不活性型 $\mathrm{Rb}$ 蛋白に なり，細胞周期は G 1 期から $\mathrm{S}$ 期に進む。この cyclin D $/ \mathrm{CDK} 4$ （6）を阻害し，細胞周期の進行を制御する因

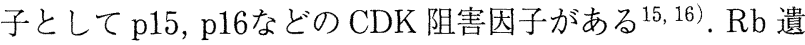
伝子の不活化は蛋白の欠失として現れ，種々の固形癌でそ の報告をみる ${ }^{17)}$. 口腔扁平上皮癌でも $56.4 \%$ に欠失を認め たとの報告がなされているが18)，今回の検索での軟部肉腫 ではその欠失は認めず, $\mathrm{Rb}$ 遺伝子の異常は示されなかっ た.しかし，一方で Rb 経路で増殖抑制に働く 16 の欠失は
1 例を除いて全例に認められた。この結果は, 口腔扁平上 皮癌で P16の異常を $67.9 \%$ に認めたとの過去の報告とほほ 同様であり，これらの癌抑制遺伝子の異常が軟部肉腫にお いても高頻度に生じていることが示唆された.しかしなが ら, これらの癌抑制遺伝子と細胞増殖能との関連は明らか にできなかった。

\section{MMP の発現と腫瘍内血管}

軟部肉腫は急速な増大と局所への浸潤や血行性転移が特 徵的な腫瘍である 1,2$)$. 口腔癌を含む種々の癌の浸潤・転 移において基底膜の破壊や周囲組織への浸潤, 転移に IV 型 コラーゲンの分解酵素コラゲナーゼ A / B である MMP- 2 と MMP- 9 が重要な役割を果たす ${ }^{19,20)}$. 今回の検索では, いずれの症例においても,この MMP- 2 およびMMP-9の 発現を認めた. Benassi ら ${ }^{21)}$ は軟部肉腫における MMPの 検討で, おのおのの腫瘍で, その発現量に差があること, 免 疫組織学的な検索による発現の違いが転移と有意に相関す ることを報告している.今回の検索で各腫瘍における発現 量の差や浸潤転移との関連は明らかにできなかったが, MMP- 2, MMP- 9 が軟部肉腫においても浸潤, 転移に関 与していることが示唆された.

血管新生は, 口腔癌を含む種々の固形癌で腫瘍の増大あ るいは浸潤, 転移に密接に関連していることが報告されて いる3 ${ }^{3,4,22)}$. 固形腫瘍ではある一定以上の大きさから急速 に増大する場合, 酸素と栄養の供給のために腫瘍血管新生 が必要であることが知られている.しかし，今回検討した 軟部肉腫では, 血管密度も 2.3-7.6/area と非常に少なく, 新生血管と思われるような微小血管の増生は認められな かった. また，一方で腫瘍周囲の血管が, 腫瘍の浸潤により 腫瘍内で破壊されているような所見が認められた。このこ とは, 軟部肉腫の血管新生を伴わない急速な局所浸潤性を 示唆するものであったが, 血管への腫瘍細胞の浸潤などは 明らかではなく, 血行性転移に関しての有意義な知見は得 られなかった。

\section{ま と め}

過去20年間に当科において加療した軟部肉腫 8 例（悪性 線維性組織球腫 2 例, 横紋筋肉腫 2 例, 平滑筋肉腫, 悪性神 経鞘腫, 未分化肉腫, 腎外性悪性 Rhabdoid 腫瘍おのおの 1 例）を検討した. 臨床診断では, 腫瘍径の比較的小さい症 例で良性腫瘍と考え，切除生検を試みたものがあり，これ らの診断は困難と思われた. 病理診断では生検にておおむ ね非上皮性悪性腫瘍の診断は得られていた. 検索可能で あった 6 例中 $\mathrm{p} 53$ の異常は 4 例に, p16の欠失は 5 例に認め られた. 高悪性で, 遠隔転移が多いという軟部肉腫の特徴 
を, 免疫組織学的に検討した. PCNA L.I.は扁平上皮癌よ りも明らかに高值を示し，高い増殖活性が確認された。 MMP- 2, MMP-9 はすべての症例において発現を認めた。 腫瘍内血管密度は扁平上皮癌に比し, 明らかに低值であり, 血管新生を伴わない急速な局所浸潤性がうかがわれたが, 血行性転移に関しての有意義な知見は得られなかった。

\section{引 用 文 献}

1) Weber, R.S., Benjamin, R.S., et al.: Soft tissue sarcomas of the head and neck in adolescents and adults. Am J Surg 92: 386-392 1986.

2) Gorsky, M. and Epstein, J.B.: Head and neck and intra-oral soft tissue sarcomas. Oral Oncol 34: 292-296 1998

3) Alcalde, R.E., Shintani, S., et al.: Cell proliferation and tumor angiogenesis in oral squamous cell carcinoma. Anticancer Res 15: 141714221995

4）新谷 悟, Alcalde, R.E., 他: ヒト口腔扁平上皮癌 における微小血管に関する免疫組織化学的検討。日 口外誌 40: 645-650 1994.

5) Shintani, S., Mihara, M., et al.: Apoptosis and p53 are associated with effect of preoperative radiation in oral squamous cell carcinomas. Cancer Letters 154: 71-77 2000.

6) Shintani, S., Mihara, M., et al.: Infrequent alternations of RB pathway (Rb-p16INK 4 Acyclin D 1 ) in adenoid cystic carcinoma of salivary glands. Anticancer Res 20: 2169-2176 2000.

7) Enzinger, F.M., Weiss, S.W., et al.: Soft tissue tumors. 3rd Ed, Mosby Co, St Louis, 1995, p539577.

8）二宮 香, 橋本 温, 他：上顎洞に発現した悪性線 維性組織球腫の 1 例。日口外誌 36: 575-579 1990 。

9) Weiss, S.W.: Histological typing of soft tissue tumors. International histological classification of tumors. World Health Organization. 2nd Ed, Springer-Verlag, Berlin, 1994, p28-30.

10) Linger, D.J. and Levine, A.J.: Characterization of a $54 \mathrm{~K}$ dalton cellular SV40-tumor antigen present in SV-transformed cells and uninfected embryonal carcinoma cells. Cell 17: 43-52 1979.

11) Yonish-Rouach, E., Grunwald, D., et al.: p53- mediated cell death: relationship to cell control. Mol Cell Biol 13: 1415-1423 1993.

12) Greenblat, M.S., Bennet, W.P., et al.: Mutation in the p53 tumor suppressor gene: clues to cancer etiology and molecular pathogenesis. Cancer Res 54: 4855-4878 1994.

13) Shintani, S., Yoshihama, Y., et al.: Overexpression of p53 is an early in the tumorigenesis of oral squamous cell carcinoma. Anticancer Res 15: 305-308 1995.

14) Ayan, I., Dogan, O., et al.: Immunohistochemical detection of p53 protein in rhabdomyosarcoma: association with clinicopathological features and outcome. J Ped Hemato Oncol 19: 48531997.

15) Lukas, J.D., Agaars, L., et al.: Retinoblastoma-protein dependent cell cycle inhibition by the tumor suppressor p16. Nature 375: 530-536 1995.

16) Serrano, M., Hannon, G.J., et al.: A new regulatory motif in cell cycle control causing specific inhibition of cyclin/CDK 4 . Nature 366: 704-707 1993

17) Boynton, R.F., Huang, Y., et al.: Frequent loss of heterozygosity at the retinoblastoma locus in human esophageal cancers. Cancer Res 51: 576657691991.

18) Nakahara, Y., Shintani, S., et al.: Alterations of Rb, P16 INK 4A and Cyclin D 1 in the tumorigenesis of oral squamous cell carcinomas. Cancer Letters 160: 3-8 2000.

19) Kurahara, S., Shinohara, M., et al.: Expression of MMPS, MT-MMP, and TIMPs in squamous cell carcinoma of the oral cavity: correlations with tumor invasion and metastasis. Head Neck 21: 627-638 1999.

20) Davies, B., Waxman, J., et al.: Levels of matrix metalloproteinases in bladder cancer correlate with tumor grade and invasion. Cancer Res 53: 5365-5369 1993.

21) Benassi, M.S., Gamberi, G., et al.: Metalloproteinase expression and prognosis in soft tissue sarcomas. Ann Oncol 12: 75-80 2001.

22) Folkman, J.: Angiogenesis in cancer, vascular, rheumatoid and other disease. Nat Med 1: 31-37 1995. 